\title{
GESCHIEDENIS TUSSEN STRUCTUUR EN WERKELIJKHEID
}

\author{
Raoul Bauer \\ in gesprek met \\ EMMANUEL LE ROY LADURIE
}

De naam van de Franse historicus Emmanuel Le Roy Ladurie is in ons taalgebied vooral verbonden met de beschrijving van Montaillou, een klein veertiende eeuws dorp in de Pyreneeën. De Nederlandse vertaling van zijn boek Montaillou, village occitan de 1294 à 1324, kende hier een opvallend succes. In dit boek leert men - althans op het eerste gezicht - deze historicus kennen als een schitterend verteller die op een bijna impressionistische wijze: zijn historische figuren tot leven weet te brengen. Bij nader toekijken evenwel, wordt het duidelijk dat niet het 'vertellen' centraal staat, maar wel het zoeken naar onderliggende maatschappelijke structuren waarbinnen de auteur zijn personages kan plaatsen. Dit gegeven verwijst ons naar een 'andere' Le Roy Ladurie zoals die vooral naär voren komt in zijn vroeger werk Le territoire de l'historien en in zijn grote studie uit 1980 L'argent, l'amour et la mort en Pays d'Oc. Hierin vinden we beurtelings de historicus die zweert bij een kwantitatieve benadering van het verleden en de structuralist die zijn historische individuen reduceert tot type-figuren uit de Europese folkloristische traditie. Kortom, zijn historische visie is niet op een welbepaalde noemer te plaatsen. Deze verscheidenheid vindt men eveneens terug in de thema's en periodes die hij behandelt warbij deze laatste zich uitstrekken van de Middeleeuwen tot - zoals in zijn recent werk de twintigste eeuw. In het kort gesteld : Le Roy Ladurie is als historicus een intrigerende figuur die soms meer vragen oproept dan hij antwoorden geeft. Dit blijkt onder andere uit het gesprek dat wij met hem hadden op 20 mei 1981, in het kader van het BRT-programma Fundamenten.

Tot uw belangrijkste publicaties behoren ongetwijfeld twee verzamelingen van artikels uit de jaren ' 60 en '70, die verschenen onder de titel Le Territoire de l'historien I et II. Wat is de gemeenschappelijke basis in al deze artikels ?

Ik geloof dat dit een materialistische en misschien ook een ietwat sciëntistische visie was op de geschiedenis. Hiermee bedoel ik een poging om het ver- 
leden te bestuderen, niet enkel op het niveau van enkele grote personages of van een paar individuen - hoewel ik meen dat men nog veel dingen kan aflezen uit de geschiedenis van de enkeling - maar ook in het vlak van de menselijke collectiviteiten en soms van de atmosferische massa's : de geschiedenis van het klimaat of van het geld. $\mathrm{Zo}$ is het de geschiedenis van de edele metalen die aan de grondslag ligt van deze laatste. Laten we bij wijze van boutade stellen dat, indien ik Napoleon op zijn paard zou tegenkomen, en indien ik in het bezit was van een bandrecorder, ik niet Napoleon doch wel zijn paard zou interviewen. Het paard interesseert mij meer dan Napoleon zelf, gezien het paard een 'personage' is, dat voortkomt uit de domesticatie die ergens in Rusland ontstond twee à drieduizend jaar geleden. Het paard incarneerde de strijdlustige aristocratie, de geperfectioneerde arbeid, en met name bij de Vlamingen, de oorlogen. Uiteindelijk werd het paard vervangen door de auto ... Het paard is dus voor mij iets boeiends, dat mij iets leert over twee à drieduizend jaar geschiedenis. Een dier dat dit ook doet - en nog in grotere mate - is de os, een os betekent tienduizend jaar geschiedenis, daar waar Napoleon op zich toch niet meer betekent dan laten we zeggen honderd jaar.

In 1975 en 1979 publiceerde $u$ twee boeken die een opmerkelijk succes kenden bij het grote publiek: Montaillou, village occitan, de 1294 à 1334 en Le Carnaval de Romans. Graag een korte situering van deze twee boeken.

Montaillou is een dorpsmonografie, een genre dat heel bekend is bij ethnologen en anthropologen en druk beoefend wordt door historici en heemkundigen. Zo schrijven ook onderwijzers op rụst graag dorpsmonografieën op basis van de parochie-archieven. Ze vertellen ons de geschiedenis van hun dorp. Ik heb in de grond hetzelfde willen doen. $\mathrm{Nu}$ is het zo, dat men over dit dorp heel wat gegevens heeft. Daaruit volgt dat men niet enkel het precieze aantal koeien in de wei kende of de exacte vorm van de akkers, maar ook de ideeën van de dorpsbewoners en dit dank zij de ondervragingen van de inquisitie. Het was weliswaar een wrede inquisitie, maar ze was intelligent bedacht en goed georganiseerd vanaf de jaren 1300 . Het is precies daar dat ik iets uitzonderlijks heb kunnen doen. Hoewel ik het succes van een dergelijk werk niet uitsloot - het was zeker niet mijn eerste bekommernis - kreeg dit werk plotseling een enorme bijval. De uitgever had het slechts op tweeduizend exemplaren uitgegeven, denkend dat het niet zo goed zou verkopen. Mijn doel was immers een heel klassiek werk te maken, vervelend, banaal, net zoals de dorpsmonografie.

Wat nu Le Carnaval de Romans betreft. Dit was een idee waar ik reeds lang mee liep. Dit boek is een werk waarin door het beschrijven van een gebeurtenis, door een vorm van evenementiële geschiedschrijving dus, geprobeerd wordt de belangrijke elementen van de cultuur van een tijdperk te achterhalen. Het karnaval - dat ook in België bekend is - is een geschikte manier om dit te bereiken. Men vindt er immers christelijke en heidense elementen in terug, alsook de 
invloeden van klassestrijd, van opstanden. Ik heb dus geprobeerd een globale visie te krijgen op een bepaalde stadsgemeenschap in de zestiende eeuw en dit via een analyse van de oproer van ambachtslui in Romans bij Grenoble. Deze revolte greep plaats gedurende de karnavalviering, de mensen hadden zich verkleed, zowel de revolutionairen als de niet-revolutionairen, elk van hun kant proberend hun opstand uit te beelden.

Men kan mij verwijten dat ik er niet in slaagde een logische structuur op te bouwen waardoor dit systeem van karnavalviering van $A$ tot $Z$ uitgelegd wordt, doch misschien is het precies dàt waarin ik later wel geslaagd ben.

Zou $u$ zelf het grote succes van deze boeken kunnen verklaren?

Ik geloof dat er heel wat mensen zijn die openstaan voor de geschiedenis, in Frankrijk zeker, en nu ook al in Engeland gezien mijn boek Montaillou een groot succes kent in Engeland. Maar aan die mensen werd vrij vaak een magere historische schotel gegeven. Verhalen over koninklijke minnaressen, oorlogen, en dergelijke meer. Over 't algemeen waren die wel goed gemaakt, maar uiteindelijk niet zo enorm interessant.

Wanneer er dan plots iemand komt die de mensen vertelt over hun voorouders, over het werkelijke leven zoals het toendertijd geleefd werd en die deze taferelen kan oproepen in waardegeladen termen, die datgene kan oproepen waarin men het vroegere leven voelt trillen, dan raakt men daarmee een gevoelige snaar bij het publiek en dan kan men het publiek boeien. Ik denk dat men dit niet aan Belgen of Vlamingen, of aan Nederlanders moet vertellen, gezien u zelf en uw cultuur volledig gekleurd zijt door de geschiedenis. Al uw problemen en al uw conflicten spruiten voort uit historische toestanden. De vorming van een land als België, het behoren tot twee culturen - met name de Germaanse en de Latijnse - maakt dat niemand zo goed als u geplaatst is om te begrijpen dat de mens zichzelf niet echt kan interpreteren, tenzij in relatie tot zijn verleden dat vaak een ver verleden kan zijn. Voor zover het $u$ betreft, moet men misschien wel teruggaan tot de Germaanse invallen van de zesde eeuw.

Hoe zou men deze twee werken kunnen situeren in het geheel van uw ceuvre?

Ik denk dat Le Camaval de Romans een geschiedpoging is om de evenementiële geschiedenis te hernieuwen door er een structuur in te steken. Een vergelijking om dit te verduidelijken. Vroeger kon men op pelgrimstochten een kleine parelmoeren pen met een vergrootglas erin kopen. In het midden van het vergrootglas zat een Onze-Lieve-Vrouwbeeldje van Lourdes, of de Eiffeltoren, of de Mont Martre, of Sint-Theresia van Lisieux. Het was dus iets heel kleins dat uiteindelijk een groot monument voorstelde. Iets in die zin heb ik ook gedaan. Doorheen iets kleins een culturele en populaire totaliteit zien. Zoals ik reeds eerder zei, is het benadrukken van het feit niet iets wat ik altijd zou doen. Ik ben trouwens een historicus van wat men in de stijl van Gramsci zou noemen 
de meridionale kwestie in Frankrijk. Ik geloof dat wij hier in Frankrijk een heel meridionaal compartiment hebben, Occitaans of anders, dat zelfs de grootte van Portugal overschrijdt en een natie op zich had kunnen zijn. Deze streek maakt deel uit van een land, heeft een barokke cultuur, een cultuur die in grote mate anders is dan de klasșieke Franse cultuur en die onze volle aandacht verdient. Ikzelf ben Normandiër en dus noordelijke, behorend tot een wat cynisch en introvert volk, en het bekijken van een barokke gemeenschap heeft mij steeds weer geboeid. Ik vermoed dat het allicht een beetje een gelijkaardige situatie is die juist bij jullie bestaat tussen het Franstalig landsgedeelte van Belgiê enerzijds en dan de volledige 'Rubenskant' anderzijds. Barok-katholiek zijnde, is Vlaanderen heel verschillend. Ik denk dat het deze fascinatie is voor het Zuiden, ik zeg niet 'l'Occitanie' want ik weet zelfs niet of dit ooit bestaan heeft of ooit zal bestaan, maar voor 'le pays d'oc', die mij toch heel erg geïntrigeerd heeft. Ik veronderstel dat zulke zaken ook in Italië voorkomen.

Zou men Le Carnaval de Romans ook kunnen beschouwen als een poging tot totale geschiedschrijving?

$\mathrm{Ja}$, ik geloof dat de 'totale' geschiedschrijving een roeping is die ik steeds in mij gehad heb, meer misschien dan de kwantitatieve geschiedschrijving. Daarom is het ook dat ik, in tegenstelling tot vele van mijn collega's, hou - zoals $\mathrm{u}$ ongetwijfeld - van Toynbee, van zijn verlangen namelijk om de civilisaties te benaderen vanuit een totaalvisie. Ik ben ervan overtuigd dat een historicus moet proberen een cultuur in haar geheel in haar diverse geledingen te lezen en dit door middel van de materiële cultuur, de gemeenschap en de religie; dat hij op die manier moet proberen te begrijpen wat er gebeurd is. Dit is wat ik wilde doen, maar ik moet toegeven dat men er in sommige gevallen beter aan doet zich te beperken tot een bepaald niveau.

Eind 1980 publiceerde $u$ L'argent, l'amour et la mort en pays d'oc, een veelomvattende enquéte over twee legenden, nl. 'Jean-l'ont-pris' en 'La Mortparrain' die als basis dienden voor een geschiedenis van de volkscultuur in WestEuropa. Waarom vertrekt $u$ van deze legenden?

Het ging om een kleine roman uit de langue d'oc uit 1756, een meesterstuk uit de Occitaanse literatuur, of met andere woorden uit de meridionale literatuur van Frankrijk. Een meesterstuk dat - de specialisten terzijde gelaten - heel weinig bekend is. Het is reeds lang dat ik dit werk wou bestuderen, reeds een twintigtal jaar zit het klaar in mijn dossiers. Ik vond het een roman, een kleine roman, die mij enorm boeide, doch ik wist niet hoe er precies aan beginnen. Toen ik enkele jaren geleden ontdekte, dat het enerzijds een samenvatting was van de volledige meridionale literatuur van twee eeuwen en anderzijds de weergave van een internationaal verhaal, dacht ik dat dit helemaal niet op die manier bekend was. Met meridionale literatuur bedoel ik het volledige Occitaanse theater, dat men zou kunnen vergelijken met het Italiaans volkstheater van de 
zeventiende en achttiende eeuw. Deze Occitaanse theaterwereld is totaal onbekend.

Ik ben ervan overtuigd dat - bij jullie net als bij ons - het enige bekende van de Occitaanse literatuur de Middeleeuwse Troubadours 'Les Troubadours' zijn. Verder kent men ook Frederic Mistral, maar wat tussen die twee ligt, blijft in het duister. Nochtans waren er die ongeveer zestig bekende theaterstukken die alle gericht wareri op het huwelijk, op de vraag hoe een jongeling gehuwd kon raken, hoe hij geld kon vinden om een meisje te huwen, hoe hij de vader van zijn geliefde om haar hand kon vragen, en ga zo maar door. Gedurende eeuwen heeft men zich daaraan geintereseeerd, omdat het hier ging om het leven van elke dag. Het had niets te maken met het politieke leven, dàt staat als een paal boven water. Maar ook is deze legende tevens de zeer intelligente verwerking van een verhaal dat thuishoort in Europa en waarvan de titel luidt La Mortparrain. Hierin is de dood de peter van een kind. Het thema van de peetvader is opnieuw beroemd geworden door een film. De Dood is peetvader van een kind en maakt er een dokter van, geeft hem rijkdom en ook de mogelijkheid om een onfeilbare diagnose te stellen : als de Dood aan het hoofdeinde van het ziekebed staat, zal de zieke sterven; als de Dood aan het voeteinde staat, zal de zieke genezen. Op een dag draait de dokter het bed van een doodzieke, waardoor de zieke aan de Dood ontsnapt, gezien de Dood nu aan het voeteinde staat. De zieke is gered, doch de Dood is woedend en wreekt zich op de held. Dit verhaal is een bestseller geweest, net als Assepoester. Het is een bestseller binnen de orale vertelkunst en heeft in alle christelijke landen een enorm succes gekend. Ook in Vlaanderen, doch niet in Wallonië wat merkwaardig is! Dit verhaal heeft er nochtans bestaan, maar is verdwenen. Dit verhaal treft men nu aan in de 'langue d'oc'.

Via een klein onderwerp, ben ik er dus in geslaagd om grote culturele aders te vinden, net zoals wanneer men naar petroleum boort, men boort een gat en opeens spuit de olie er uit. Ik pretendeer zeker niet alle problemen te kunnen oplossen die in verband staan met de Franse betalingsbalans... maar het principe is misschien hetzelfde.

Graag nog een kleine opheldering die niet zonder belang is, namelijk het grammaticaal geslacht van de woorden Dood en Peter. In de Latijnse talen is de Dood een vrouwelijk woord. De vraag rijst hoe een vrouwelijke entiteit nu peter kan zijn?

Ik veronderstel dat de Dood in uw taal van het mannelijke geslacht is?

Het is zowel mannelijk als vrouwelijk.

Ook in het Vlaams is het dus vrouwelijk ?

Ja.

In elk geval, in het Duits is het 'der Tod', dus mannelijk en aan de oorsprong ligt een woordspeling die men terugvindt in de Franssprekende gebieden. 
De Duitse cultuur - die hier toonaangevend is geweest - beheerste centraal Europa en van hier zijn zovele waardevolle zaken tot bij ons doorgedrongen. Ook al zijn wij niet geneigd te appreciëren wat de Duitsers ons gedurende bepaalde periodes aangedaan hebben, wij zijn ergens wel eerbied verschuldigd voor deze wondere culturele wereld die de Germaanse toch is. Dus, in de Franssprekende gebieden van de veertiende eeuw bestaat datzelfde woord, dat in het plaatselijke dialect zowel 'Dood' als 'Peetvader' betekent, namelijk 'Tode', de dood, en 'Tote' of 'Tode' of 'Dod', wat Peetvader betekent. Hetzelfde vindt men terug in het Engels, namelijk 'death' (dood), 'deaddy' (vader). In feite betekent dit 'la mort-parrain', maar ook 'la mort papa'. Dit wil dus zeggen dat de kinderen kunnen kiezen tussen twee woorden om papa te zeggen. Er zijn heel wat talen waarin kinderen papa zeggen, anderen zeggen dada, hetgeen dus neerkomt op death, deaddy, tote, dod, dood, vader, ... de dood-vader. U merkt diverse interpretaties die men er aan kan geven. Wat er ook van zij, uiteindelijk heeft de idee van een dood-vader, van een dood-peter (de idee komt telkens terug) veel succes gekend en men heeft er een verhaal op gebouwd, dat zowat overal verspreid werd. Dan daagt natuurlijk het probleem op, eens men Duitsland verlaat en het verhaal in een land terechtkomt waar de dood van het vrouwelijk geslacht is. Ik weet niet welk het grammaticaal geslacht is van de 'Dood' in het Nederlands, maar in het Latijn, het Italiaans, het Spaans, en in het Frans is de dood vrouwelijk : la mort, la morte, ... Wat doet men in zo'n geval ? Wel, er zijn verschillende oplossingen mogelijk, ofwel maakt men er bij voorbeeld een meter van, ofwel een peter met een meisjesnaam, er bestaat meer dan één mogelijkheid en de folkloristen hebben zich goed uit de slag getrokken.

Wat de zaken wel iets ingewikkelder maakt, is het feit dat een peetvader niet bestaat in niet-christelijke landen, of bij het Joodse volk, de Turken of Perzen. In die gevallen, zelfs in de Grieks-orthodoxe wereld, maakt men van de Dood over 't algemeen de Doodsengel, de Dood wordt dus de Doodsengel en de held is niet zijn petekind, maar zijn zoon of zijn beschermeling.

In een waarschuwing aan de lezer stelt, $u$ het belang van de verhouding fictie-historische feiten in het licht, hetgeen ik een zeer aanvaardbaar en sympathiek standpunt vind. Niettemin hierover toch éen enkele opmerking : u gaat daar niet zo heel diep op in. Laat mij toe me nader te verklaren: het schema van het verhaal 'La Mort-parrain' is niet steeds hetzelfde. In bepaalde versies triomfeert de Dood over de held, in andere versies eindigt alles in een 'Happy End' en in nog andere versies wordt de Dood schaakmat gezet door wat $u$ zelf noemt een entiteit waarvan men per definitie heel goed weet dat ze steeds aanwezig zal zijn als de Haat en het Verlangen in de Vlaamse versie. Wat bepaalt nu precies de inhoud en de compositie van deze verhalen? Is het de periode of de streek misschien? 
Naar mijn mening krijgt een verhaal - eens het gelanceerd is - iets eeuwigs over zich. Wij lezen bij voorbeeld nog steeds de Ilias en Odyssee en laten ze onveranderd, wij doen geen enkele poging om ze aan te passen aan onze huidige samenleving. Men kan bij voorbeeld Shakespeare wel in een modern kleedje opvoeren, doch ideaal is dit zeker niet, maar goed, er zijn diverse versies mogelijk. La Mort-parrain is één der zeldzame volksverhalen dat slecht afloopt, waarin - hetgeen normaal is - de Dood zegeviert en de held gedood wordt, daar waar in gewone verhalen het slot steeds luidt : zij leefden nog lang en gelukkig en hadden vele kinderen. In bepaalde gevallen echter is de held een onsterfelijke entiteit en eindigt het verhaal op een happy end. De held kan Schaarste, Hongersnood, Armoede, Bedrog, Miserie, Haat of Verlangen heten, en iedereen weet dat, zolang de wereld zal bestaan, er haat zal zijn, verlangen, honger, miserie. In die gevallen leidt men de Dood om de tuin, de Dood blijft in zijn pereboom zitten en kan er niet uitkomen. De held is eeuwig, een beetje zoals men vindt in het thema van Le Juif Errant. Daaruit volgt het bestaan van die andere versie. In welke eeuw dan ook, vindt men dat verhaal terug in die beide versies. De versie Haat en Verlangen bij voorbeeld, die men in Vlaanderen terugvindt, is blijkbaar uit Italië afkomstig, gezien een Italiaans, of misschien een Duits, schrijver voor het eerst de 'Haat en Verlangen'-versie voorstelde in 1550. Zoals u weet had Vlaanderen nauwe contacten met Italië. Ik durf veronderstellen, dat een Italiaanse mondelinge versie in Vlaanderen in de bloeitijd van de Italiaanse handelaars in Vlaanderen doorbrak. Vandaar komt dus deze versie waarin Haat en Verlangen erin zullen slagen de Dood te bedriegen en eeuwig te overleven. In Québec is het de Schaarste, maar in Vlaanderen bestaan er ook versies waarbij de held op het einde door de Dood verslagen wordt.

Ik geloof dat een verhaal heel lang kan overleven, omdat het onze gevoeligheid blijft aanspreken. Dit is ook zo met de Ilias en de Odyssee, alsook met bepaalde klassieke verhalen uit de Oudheid. Dit is het geval met sommige Japanse films die ons over de cultuurbarriëres heen blijven aanspreken.

\section{Is Jean-l'ont pris niet vóór alles een held uit de Verlichting ?}

Ik geloof dat de Verlichting de oudste helden terug tot leven geroepen heeft. Het bekendste voorbeeld, dat overigens meer romantisch is dan wat dan ook, is Faust. Faust die een pakt tekent met de Duivel en die dank zij deze overeenkomst steenrijk wordt. Ik denk dat dit een oude Duitse mythe is - zeker weet ik het niet - die naar ik meen door de Engelse dramaturg Marlowe herwerkt werd, het lijkt mij in de Elisabethaanse periode of zoiets in die buurt. Goethe op zijn beurt gaf er dan een buitengewone dimensie aan.

Mijn held - deze Jean t'ont-pris - is ietwat verschillend. Hij tekent een pakt, niet met de Duivel, maar met de Dood. In die zin is hij wel één van die helden afkomstig uit de Verlichting. Hij slaagt er misschien wel in sterker te zijn dan de Dood, in elk geval toch sterker dan de gebeurtenissen en wordt dan 
meegesleurd in het Faustische élan van de Verlichting. Maar het leidt geen twijfel, dat dit soort helden tot op heden bestaat en eigenlijk van alle tijden is.

De overgang van de kindsheid of van de jong volwassenheid naar een meer volwassen leeftijd houdt een initiatie in. In veel culturen komt deze initiatie tot stand door een contact met het hiernamaals of wat men pleegt te noemen het Rijk der Doden. In de Afrikaanse en in de Indiaans-Amerikaanse culturen betekende deze initiatie een stage die een jongeman moest doormaken in de vrije natuur, samen met zijn beschermgeest. Bij de Spartanen werd het kind in volle natuur gegooid, zijn buik werd open gebeten door een vos. Zo zijn uiteindelijk heel wat verhalen ontstaan. Bij ons bestaat ook nog zoiets in die zin onder de vorm van de militaire dienstplicht als overgang naar de mannelijkheid ... het leren sigaretten roken en afspraken maken met de vrouwen, enzovoort. In de legenden vindt men vaak deze elementen terug en de essentie van vele sprookjesverhalen en fantastische verhalen is een reis van de ziel na de dood, de held die op een bepaald ogenblik een reis maakt naar het hiernamaals, die contact opneemt met de doodskrachten, met de Dood zelf, met de overledenen of met de Duivel, waaruit hij gesterkt terugkomt en in het bezit is van gaven die hem toelaten te slagen in het leven. Vanzelfsprekend dient daardoor een prijs betaald te worden, want een pakt tekenen met de Dood gebeurt niet zomaar.

Mag men stellen dat de figuur van La Mort-parrain zou kunnen geboren zijn uit een tragische sociale en economische situatie, die onder andere gekenmerkt werd door het voedseltekort ?

Wel, het is meer dan dat. La Mort-parrain is één van die zeldzame verhalen waarvan wij heel precies weten wanneer het uitgevonden werd. Vele verhalen kwamen bij ons terecht, doch ze bestonden reeds in het oude Egypte en Indië; dit klinkt heel aannemelijk, gezien de wortels van onze beschaving Indo-Europees zijn. En of we nu Latijns of Germaans zijn, vele sprookjes komen uit de oude godsdienst van Indië. La Mort-parrain daarentegen is een verhaal waarop men een precieze datum kan kleven. Het werd in Duitsland uitgevonden rond 1300-1350 in functie van het woordspel 'Tode-Dot', 'Death-deaddy', 'Mortparrain' en paste in de sfeer van het macabere die er heel wat toe bijgedragen heeft. Vanaf 1348 was er de zwarte pest die veel mensenlevens opeiste, net als een soort atoomoorlog. De mensen van toen leefden dus in de sfeer van de dood; dit werd door één van uw grote historici Huizinga goed uiteengezet in zijn boek Herfsttij der Middeleeuwen. En precies in deze sfeer van de dood is het normaal dat het personage van de Dood er één is van een wijze, van iemand die - net als de historicus - bewaarder is van alles wat voorbij is, die éénoog is, cycloop, want éénogen zijn wijzen, wetenden, zij hebben toegang tot geheimen waartoe anderen geen toegang hebben. Kortom, deze personages zijn zeer belangrijk.

Dit alles overleeft die macabere tijd en komt daarna terecht in de barok en 
leeft zelfs nu nog voort. In het Zuiden van Frankrijk werden de laatste versies van La Mort-parrain, die ik ken in Ariège in 1965 teruggevonden en het zijn vaak goede versies die werkelijk archaïsche trekken bewaarden. Voor wat het voedseltekort betreft moet ik ja antwoorden, maar in Québec bij voorbeeld, heet de held die over de Dood triomfeert vaak Vader Schaarste. Om voor mij onbekende redenen werd hij daar in Québec zo gepresenteerd. Gesteld dat er in het begin honger geleden werd en deze legende op dat ogenblik nog niet bestond, is het vanzelfsprekend dat ze hem Vader Schaarste noemden. Elders, zoals ook in Frankrijk, heet hij 'le bonhomme Misère'. Bij jullie in Vlaanderen bestaat de magnifieke versie die 'Hop, in mijnen Zak' heet en die absoluut een uitzonderlijke versie is van $L a$ Mort-parrain, het is één der mooiste versies die bestaan.

In uw boeken en in wat u zopas komt te zeggen, vindt men veel verwijzingen naar Vlaanderen. Waarom?

Zoals u weet, voel ik mij aangetrokken door minderheidsculturen. In eerste instantie ben ikzelf Normandiër en mijn volk is een beetje in verval geraakt sinds wij in 1066 Engeland 'civiliseerden'; wij leven nu nog steeds verder in tamelijk constant afdalende lijn. Wij hebben wel iets groots gepresteerd. Maar goed, het zijn de minoriteiten die mijn belangstelling wegdragen. De Vlamingen zijn in België natuurlijk geen minderheid, maar ruimer gezien kan men stellen dat de Nederlandse cultuur zowat in de minderheid staat ten opzichte van de Franse of Duitse cultuur en meer nog tegenover de Engelse cultuur. Dergelijke culturen vind ik uiterst boeiend. Deze minderheidsgroepen brengen soms hele grote teksten voort. Ook verwerken zij vreemde gegevens, wat zijn belang heeft. Meer in het bijzonder geloof ik dat de minoritaire katholieke culturen ons heel wat te vertellen hebben. De dominerende katholieke of protestantse culturen baseren zich uiteindelijk op tamelijk universele culturen, zoals bij voorbeeld in Frankrijk de Jansenistische cultuur die in feite ook in Wallonië de overhand had. Verder heeft $u$ dan nog - naast de Jansenistische cultuur - de Jacobijnse culturen, de lekenculturen en de nationalistische culturen. Dit is ook de reden waarom u La Mort-parrain niet in Wallonië zult vinden. Ik denk dat de pastoors moeten gezegd hebben : luister, die verhalen over de Dood die mirakels doet, dat is helemaal niet katholiek !

Precies die mythe van La Mort-parrain zult $\mathrm{u}$ daarentegen terugvinden in Bretagne en in le pays d'oc, doch zij zal bijna onvindbaar zijn in het Noorden van Frankrijk waar zij van de kaart geveegd werd door de Cartesiaanse en Jansenistische cultuur. U zal ze slechts sporadisch terugvinden in Wallonië en heel weinig in Engeland, doch wel in Ierland. Daaruit blijkt dat Belgisch Vlaanderen, Ierland, le pays d'oc en Bretagne barokke katholieke culturen zijn. Nu is dat totaal veranderd, Vlaanderen is een heel modern land en gaat zich een beetje op Nederland richten en op de naburige landen. Gedurende lange tijd echter, heeft men het katholicisme op zijn Brueghels bewaard, dat uit folkloristisch 
oogpunt gezien extreem rijk is.

Als we uw werk in zijn totaliteit beschouwen, springt één zaak in het oog. namelijk de diversiteit zowel qua inhoud als qua vorm. Men vindt er inderdaad zowel rurale geschiedenis als stadsgeschiedenis, zowel de verwerking van 'la longue durée' als evenementiële geschiedschrijving. Daaruit rijzen enkele vragen. Eerst en vooral, welk is het specifiek domein van uw werk als historicus?.

In feite geen enkel. In theorie ben ik een 'zeventiende-eeuwer', dus een specialist van de zeventiende eeuw. In feite heb ik heel weinig geschreven over de zeventiende eeuw, ik ben dus een zeventiende eeuwer die niet over de zeventiende eeuw schrijft ! Laten we zeggen dat ik een specialist ben van het tweede millenium van ons tijdperk, met een oog op het eerste en misschien ook op het derde, hoewel ik van dat laatste niet zeker ben, ik doe geen studies over de nabije toekomst. lk stel belang in wat men het Ancien Régime zou kunnen noemen, de traditionele gemeenschappen.

Ik zie ze als het ware geboren worden - niet echt geboren worden ingeburgerd raken rond 1300-1330, vóór de zwarte pest. Ze verdwijnen zomaar, zoals men het zou kunnen noemen als 'Jeanne-d'Arc-verdwijningen', eigen aan die tijd.

De grote vernielingen door de pestgolven, de herfst van de Middeleeuwen, ze komen terug en ontpoppen zich in de miserie. Het is trouwens niet zo aangenaam om in die tijd te leven, vooral niet als arme, maar ook de rijken kregen alle mogelijke vervelende ziektes en dat duurt voort tot $1830-1850$, in vele streken soms tot 1920-1950. Vandaag de dag zijn ze misschien verdwenen of gewoon totaal anders geworden. Het zijn deze drie of vier eeuwen die mijn belangstelling wekten en in de grond interesseer ik mij aan alles wat geen deel uitmakt van de 'Grote Cultuur', van de 'Grote Geschiedenis'. Racine noch Shakespeare interesseren mij, wel het volkstheater en de sprookjesverhalen, niet Lodewijk XIV interesseert mij maar wel zijn hovelingen. Ik ben een groot lezer van Saint Simon en ik hecht belang aan de landbouwers, aan de steden, aan de massa's, aan de klimaten, aan de geschiedenis zonder mensen, aan alles wat niet werkelijk schittert, wat niet heel groot is, hetgeen dus eigen is aan de massa, aan de gemiddelde mens, ...

$U$ houdt dus wel een zeer ruim terrein vrij voor de historicus. In een onderhoud met de Franse filosoof Michel Serres bevestigde $u$ dat de geschiede$n i s$ de gehele mens is min het heden. Uitgaand van $u w$ werk en van wat $u$ zopas komt te zeggen, heb ik de indruk dat $u$ vertrekt van een andere thesis: het volledige verleden min het heden met of zonder de mensen. Wat denkt u over deze interpretatie?

Op een manier is dat waar, doch slechts het verleden in de mate waarin het kenbaar is door de archieven. De macht van de historicus ligt immers in zijn kennis van de archieven. Men kan bij voorbeeld de geschiedenis van het klimaat 
maken in die mate waarin de archieven er melding van maken en de natuurkundigen niet in staat zijn om die te leren. Ze kunnen wel Engels, maar daar blijft het ook bij, ze kunnen geen Latijn, geen Duits, geen Frans of geen Vlaams, ze kunnen niets, zij zijn bijgevolg niet bevoegd het dagboek van een pastoor uit de veertiende eeuw te lezen of het dagboek van een notaris uit de zestiende eeuw. Daarvoor hebben ze de historicus nodig. De historicus is de mijnwerker van de ondergrond, de dagloner die kolen ophaalt, die grondstoffen gaat delven en deze aan de oppervlakte brengt. Pas daarna kunnen de echte 'denkers', de exacte wetenschappers dit interpreteren, maar wij - historici - verschaffen hen de kolen. Ik zou zelfs nog verder durven gaan in mijn stelling, de geschiedenis is op een manier bijna 'allesetend'.

lk geloof dat de historicus Chaunu in zijn werk La Violence de Dieu de geschiedenis uitgebreid heeft tot het totale verleden van ons universum. Hij ging uit van de 'big bang' de beginexplosie van ons universum, en gezien Chaunu christen is, heeft hij deze ge identificeerd met de schepping van de wereld door God : 'fiat lux', dat het licht weze. De grote 'boum' is er geweest, en effectief, het was licht. Daarnaast is er ook het boek Les 3 premières minutes de l'Univers. Een zeer natuurwetenschappelijk werk, maar toch met raakpunten aan de geschiedenis. Dit liet hem toe het volledige verleden van ons universum te integreren in een historische visie over de wereld. Dit gezegd zijnde, maakt dit genre astro-physische geschiedenis niet het voorwerp uit van de studies der historici, dit is het werkterrein van de positieve wetenschappers, van de $\beta$-wetenschap. Maar reeds op het gebied van de paleontologie zijn we op een terrein van de geschiedenis, gezien dit niet meer volledig geschematiseerd is, maar de werkelijke geschiedenis met haar gebeurtenissen en rampen betreft. Waarom zijn de dinosaurussen uitgestorven? Er was blijkbaar geen interne noodzaak, tenzij deze van de dood die universeel is. De paleontologie vormt reeds de geschiedenis, niet de nomothetische geschiedenis die wetten vastlegt, maar de ideografische geschiedenis die de feitelijke geschiedenis vertelt.

Geschiedenis en prehistorie, paleontologie en de geschiedenis van de mens, wel, de wetenschappelijke bladen zitten enorm verveeld met het onderscheid. Om redenen die ik niet goed begrijp, behandelen wetenschappelijke tijdschriften de paleontologie, de prehistorie en de archeologie, doch over de geschiedenis zelf zwijgen ze in alle talen. Dit onderscheid vind ik wel arbitrair.

\section{Zou men u een structuralist kunnen noemen ?}

Neen, niet echt. Ik heb grote bewondering voor Claude Lévi-Strauss, alsook voor elke vorm van wetenschappelijke vooruitgang. Onder wetenschappelijke vooruitgang bedoel ik iets anders dan slechts feitenmateriaal verzamelen, ik bedoel elke stap die gezet wordt om een bepaalde orde te scheppen, om een lijn te vinden, een ordening in de schijnbare wanorde. Dit is wat ik gedaan heb en ik ging ermee door op zoek naar een structuur. Bij voorbeeld in het laatste 
boek L'argent, l'amour et la mort heb ik een verhaal met een zekere structuur die men doorheen vier eeuwen kan volgen. Deze structuur kan men, mits men enkele kleine wijzigingen aanbrengt, toepassen op misschien wel tweehonderd versies van dit verhaal in een twintigtal christelijke en niet-christelijke landen. Het echt structuralisme gaat veel verder dan dat, maar echte structuralisten zijn over 't algemeen geen historici. Vooral Lévi-Strauss probeerde enerzijds aan te tonen dat er een enorme vormenstructuur bestaat van mogelijke familierelaties binnen dewelke diverse gemeenschappen gekozen hebben, dat wil zeggen een beetje op goed geluk de familiale vorm uitpikten die hun lag. Anderzijds bestudeerde hij mythen, legenden, sprookjes uit heel Amerika en hij toonde aan hoe deze mythen in elkaar overgingen. Ik geloof dat hij er een honderdvijftigtal bestudeerde die men kan volgen van de Amazone tot de Rocky Mountains, van Zuid- tot Noord-Amerika. Deze mythen die heel precies in elkaar passen, die vervormd raken, die anders worden, het is alsof we van Assepoester over Ezelsvel overgingen tot La Mort-Parrain en dit via een serie opeenvolgende gedaanteverwisselingen. Dit is echter het werk van ethnologen in een tamelijk eenvoudige wereld zoals de Amerikaanse waar de Indianenstammen verhalen uitwisselden. Vooral omdat Lévi-Strauss het probleem van de grote Mexicaanse of Peruvianse rijken totaal terzijde hield, die mij ingewikkelder lijken. Wij, historici, daarentegen, wij bestuderen wel ook zulke kleine structuren en volgen ze doorheen de eeuwen, maar wij maken ons geen illusies. Deze structuren zijn net als geraamten in geologische lagen, men vindt er verschillende en er zijn onderling geen absoluut noodzakelijke relaties.

Voortgaande op uw historische visie, zoals ik die terugvind in $u w$ boeken, begrijp ik uw bewondering voor de Engelse historicus Toynbee niet goed.

Eén ding is zeker, ik bewonder iemand die een poging doet om de universele geschiedenis te begrijpen, dit misschien omdat ikzelf eerder monografieën schrijf. Ik heb getracht via het particuliere tot het universele te komen, maar iemand die zich onmiddellijk aan het universele waagt, dwingt mijn respect af. Dit is trouwens ook de reden waarom ik mijn leermeester Fernand Braudel zo bewonder. Toynbee en Spengler (Marx ook, maar op een andere manier) hebben mij steeds geboeid en ik weet dat Oswald Spengler - die ik las op zestienjarige leeftijd - mij enorm geïnteresseerd heeft. Hij werd uitgebuit door de Nazi's en misschien heeft hij wel af en toe Nazi-neigingen gehad en in die mate beveel ik zijn lectuur niet aan, dat ware té eenvoudig. Bij Toynbee vindt men dat 'Nazi-complex' nergens terug, wel integendeel. Er is de idee om culturen te nemen en ze te volgen zoals men plantenspecies volgt, als blijvende entiteiten, doorheen duizenden jaren. Deze aanpak lijkt me heel interessant en persoonlijk vind ik dat de samenvatting van deze talrijke volumes zich vlot laat lezen, net als een roman. lets dat wel gezegd mag worden, is dat Toynbee absoluut geen materialist is. Hij is een idealist met een diepgaande interesse voor reli- 
gies, voor de intellectuele en artistieke cultuur, de oorlogen. Dat is allicht niet voldoende. Dat Toynbee soms misprezen wordt, is misplaatst, men heeft ongelijk.

Ik vraag me af wat de mens voor $u$ betekent. Men spreekt reeds over een 'l'homme Le Roy Ladurien' zoals Emmanuel Todd in Le Monde.

Ik pretendeer niet een auteur te zijn van een bepaald systeem, integendeel. Ik meen te gelovien dat men een onderscheid moet maken tussen de mens die de wereldgeschiedenis wijzigt en hij die er zich aan onderwerpt. Een man die de wereldgeschiedenis grondig gewijzigd heeft, is bij voorbeeld Lenin, die als eenzame banneling in Zwitserland de bizarre idee opvat dat de macht een hefboom is, waarmee men de gemeenschap kan veranderen. In oktober 1917 doet hij een kleine nietsbetekenende staatsgreep in Leningrad, maar vandaag zijn er één miljard mensen onderworpen aan dit regime. Persoonlijk ga ik helemaal niet akkoord met dit systeem, maar ik constateer dat één man de wereldloop werkelijk veranderd heeft en dit uitgaand van een kleine beslissing, een kleine actie. Uiteraard, indien het Lenin niet geweest was en indien het niet in Rusland was gebeurd, zou het wellicht elders voorgevallen zijn. Er zou in elk geval ergens iets gebeurd zijn. Maar goed, dáár is iets belangrijks gebeurd.

In de gewone dagdagelijkse loop der geschiedenis liggen de zaken wel wat anders. Fenomenen zoals culturele of demografische krachten, zoals de groei, waaraan men ongetwijfeld gebonden is en die men in de wieg meekrijgt als een gegeven situatie, die een goed of een kwaad zijn, ... het is vooral daaruit dat de geschiedenis gemaakt wordt.

Wie leidt nu volgens $u$ de loop van de geschiedenis?

Als men de christenen moet geloven, is het God, als men de Marxisten moet volgen, is het de economie. Hoewel, bepaalde Marxisten hebben nu de religie aan de infrastructuur toegevoegd in wat men de economische krachten noemt. Ik weet dus niet of we hen nog Marxisten kunnen noemen, maar deze handelwijze laat hen toe de gehele ethnografie te recupereren. Dit is wellicht een goocheltoer, maar voor de rest ... nis ?

Ja, maar wie leidt nu volgens Leroy-Ladurie de loop van de geschiede-

Laten we een voorbeeld nemen. Er bestaan heel wat verschillende acteurs en even zoveel verschillende krachten. Nemen we bij voorbeeld de Europese geschiedenis - bijna een wereldgeschiedenis - van de dertiende tot de achttiende eeuw. Wat zijn hier de centrale gebeurtenissen ? Is niet een bepaalde groei het werk van de mens, van de Westerlingen, een soort verlangen naar een steeds meer bereiken dat deel uitmaakt van de Europese cultuur van deze tijd ? Dit is bij voorbeeld een motor. Deze motor zet op zijn beurt contacten in beweging die dan epidemieën veroorzaken en het zijn precies die epidemieën die een enorm belang hebben in de geschiedenis rond die periode. De Genuese handelaars gin- 
gen in de dertiende eeuw naar China om er zijde te halen. Een keizer - Gengis Kahn genaamd - had Eurazië op een wrede wijze verenigd en had daardoor een vrede gecreëerd waardoor de handel vrije doorgang kreeg. Op een dag zijn microben doorgebroken, met name de microben van de pest. $Z$ ij vernielden de helft van de Europese bevolking en hebben de Europese geschiedenis gekleurd tot rond de zeventiende en achttiende eeuw. Indien dit voorval met de zwarte pest niet gebeurd was, of indien de epidemieën door de steeds vermenigvuldigde contacten tussen de volkeren veroorzaakt, niet hadden plaatsgevonden, liepen wij op deze wereld misschien rond met twee miljard mensen meer dan nu het geval is. Hierdoor zouden ernstige demografische problemen gerezen zijn, problemen waarvoor wij nu angst hebben dat ze zouden opdagen in de eeuw die komt.

$\mathrm{Na}$ de Genuezen, die Frankrijk reeds met de zwarte pest besmet hadden, worden via Christoffel Columbus de Indianen in Amerika aangetast. Arme Indianen, ze werden opeens overvallen door alle mogelijke Europese ziekten. Daar was het drama nog groter, men șchat het aantal slachtoffers op meer dan negentig procent van de inboorlingen, Mexicanen, Peruvianen en anderen. Dit is dus echt een voorbeeld van een geschiedenis waarin de microbe alles domineert en de mens totaal in haar greep heeft. Ik moet toegeven dat dit wel een extreem geval was.

Het staat trouwens vast dat de mens zijn eigen geschiedenis maakt, maar hij weet niet welke geschiedenis hij maakt en hij maakt ook niet de geschiedenis zoals hij die wil. Ik ga ermee akkoord, dat dit Marxistische formules zijn die ik hier paraphraseer. Dit betekent niet dat ik daarom Marxist ben, maar dat is een ander probleem.

Laten we bij voorbeeld Pasteur nemen. Hij ontdekt het rijk van de microben. Hij grijpt hier in ten voordele van het mensdom en verlost ons aldus van een aantal wrede en bedroevende ziekten. Maar hiermee schept hij voor de totale mensheid het meest formidabele probleem dat ons te wachten staat, met name het demografisch probleem, de vernietiging van het milieu, de kans op grote wereldconflicten in de eeuw die komt. Hier hebben we dus iemand als Pasteur, die het beste voorbeeld is van een vrijheid, gebruikt in functie van een reële behoefte. Maar deze vrijheid draait echter totaal anders uit dan voorzien en eindigt in een soort wilde vernieuwing, in een ongecontroleerde demografische uitbreiding. Hiermee probeer ik geenszins de genocide goed te praten, wel integendeel. Het is goed om mensenlevens te redden, maar de consequenties die gevaarlijk zouden kunnen worden indien ze niet op één of andere wijze onder controle gehouden kunnen worden, dienen vermeden.

Het voorbeeld van Lenin, dat ik hier eerder aanhaalde, is eveneens heel typisch in dat vlak. Lenin was de vernieuwer en de man die met alles wou breken en hoopte een nieuwe wereld te creëren. En wat vloeide er uiteindelijk voort uit al zijn inspanningen en wat deed zijn min of meer trouwe volgeling Jozef 
Stalin ? Er ontstond een rijk dat in de grond het menselijk avontuur, zoals het begonnen was in het Westen, met name in de Nederlanden en in Vlaanderen sinds de elfde eeuw, opnieuw bevroor. Een soort nieuwe verkilling van de gemeenschap. Er is een immens deel aan menselijke 'loomheid' dat behoort tot de dagdagelijkse sleur van de geschiedenis. Maar er zijn ook een aantal breuken en destabilisaties die zich regelmatig tegen zichzelf keren en alzo nieuwe krachten doen ontstaan.

De liberale historicus heeft oog voor de gedeeltelijke vernieuwing, de sectoriële verandering, de vernieuwing die simpelweg slechts een deel van het totale sociale leven wijzigt zoals bij voorbeeld een nieuw model van ploeg, een nieuwe sociale wet, en dergelijke meer. Wat de vernieuwing over de gehele lijn betreft, die schept zovele onvoorziene feiten, zovele gevaarlijke gevolgen, dat men er niet meer in slaagt ze in bedwang te houden en men kan nieuwe behoeften en weer andere vernieuwingen niet meer tegenhouden. Maar in feite kunnen wij hierin niet zelf kiezen. 